\title{
Increasing Efficiency of Activated Sludge Process in Domestic Sewage Treatment by Compromising Rate of Dissolved Oxygen with Ambient Temperature
}

\author{
N. Saoud*, M. Fergala ${ }^{\dagger}$, N. Abdel Mutaal ${ }^{\ddagger}$, N. Amer ${ }^{\S}$
}

\begin{abstract}
The objective of this research is to study the effect of ambient temperature on the activity of aerobic bacteria in the activated sludge process and consequently, the efficiency of biological treatment of domestic sewage. The activated sludge process is one of the environment-friendly systems so as the progressive enhancement of the system is quite essential. In rural zones are military troops zones like Air-Force airports that are mostly located in rural zones where global sewerage system cannot be provided. Such situations need an optimized, integrated simple and potential treatment system for the sewage generated from the residents and personnel working over there. The target of optimizing the activated sludge is conducted intensively within this research via investigating the inter-relationships of temperature, dissolved oxygen as well as the efficiency of biological treatment process. All of these parameters are elaborated by measuring the decrease in $\left(\mathrm{BOD}_{5}, \mathrm{COD}\right.$ and TSS). An experimental model scale system has been designed and built-up at El-Berkah Sewage Treatment Plant site located to the north-east of Cairo, Egypt. The experimental system is fed with primary-treated sewage. The characteristics of experimented sewage have been varied widely over the experimental period that extended to more than one year. Samples of wastewater have been collected every week and analyzed for many parameters including (DO, TSS, $\mathrm{BOD}_{5}, \mathrm{COD}$ ) as well as solid fractions. The experimental set up is scaled for temperature changes only in the range of $\left(10-45^{\circ} \mathrm{C}\right)$ and dissolved oxygen (2-4) $\mathrm{mg} / \mathrm{l}$. All other operating parameters such as dissolved $\mathrm{O}_{2}$ and MLTSS are set constant all over the experimental period. The results of the experimental work reveal that the optimum operating temperature of the system is $25^{\circ} \mathrm{C}$ with respect to the removal of (TSS, BOD 5 ) and COD (93, 97, and 95\% respectively). Besides, it is shown that when the ambient temperature is in the range of $10-20^{\circ} \mathrm{C}, \mathrm{DO}$ should be increased to raise removal ratio. On the other hand, when the temperature is raised more than $35^{\circ} \mathrm{C}$, DO showed considerable decreases accompanied with indications of generation of filamentous bulking.
\end{abstract}

Keywords: Efficiency of Activated Sludge Process, Domestic, Experimental model system and analysis.

\footnotetext{
"Syrian Armed Forces, noaman2019@yahoo.com

$\dagger$ Ain Shams University Faculty Of Engineering, defergala@ hotmail.com

Egyptian Armed Forces, Nabil_stars@ hotmail.com

${ }^{\S}$ Egyptian Armed Forces, NabilAmer63@yahoo.com
} 


\section{Introduction}

Sewage treatment is a multi-stage process to renovate wastewater before it reenters a body of water, applied to the land or is reused .The goal is to reduce or remove organic matter, solids, nutrients, disease causing organisms and other pollutants from wastewater. Each receiving body of water has limits to the amount of pollutants it can receive without degradation. Therefore, each sewage treatment plant must hold a permit listing the allowable levels of biological oxygen demand (BODs), chemical demand (COD), suspended solids (S.S), coliform bacteria and other pollutants.

In addition to this, an investigation was carried out on the effect of temperature (wastewater), and the dissolved oxygen source (air or oxygen) on the removal of soluble(S.S, BOD, ,COD) during the simulated aerobic, and the subsequent primary settle ability, in order to establish the optimum operating conditions for further experimental work.

The effect of temperature fluctuations on bacterial community structure and function in labscale sequencing batch reactors treating bleached kraft mill effluent was investigated. An increase in temperature from 30 to $45^{\circ} \mathrm{C}$ caused shifts in both bacterial community structure and function[1].

The impact of temperature on biogenetic constants used in the design and operation of activated sludge treatment facilities is presented. Three temperatures $\left(10^{\circ} \mathrm{C}, 20^{\circ} \mathrm{C}\right.$, and $\left.30^{\circ} \mathrm{C}\right)$ are evaluated for their impact on substrate removal, biomass concentration, waste sludge production, and oxygen requirements. The biokinetic equations developed by Lawrence and McCarty (1970) are utilized [2].

Effects of temperature on the composition of Extracellular Polymeric Substances (EPS) from 3 types of activated sludge (from treatment of municipal wastewater and anaerobic, aerobic treatment of Cola wastewater) were investigated. The results showed, for all of the three types of EPS, the compositions were most stable at $20^{\circ} \mathrm{C}$, most changeable at room temperature. The situation at $4^{\circ} \mathrm{C}$ was the medium of that at $20^{\circ} \mathrm{C}$ and room temperature. EPS from municipal wastewater sludge and aerobic treatment of Cola wastewater were seemed proper to be stored at $-20^{\circ} \mathrm{C}$. In this way, the changeable rates of these two types of EPS were $9 \%, 20 \%$ for protein concentration respectively and both of $20 \%$ for sugar concentration. Changeable rates of EPS from anaerobic treatment of Cola wastewater were high at all of the three temperatures (at room temperature; protein, $85 \%$; sugar, $80 \%$. at $4{ }^{\circ} \mathrm{C}$; protein, $80 \%$; sugar, $70 \%$. at $20^{\circ} \mathrm{C}$; protein, $30 \%$; sugar, $60 \%$ ), suggesting this type of EPS is not proper to be stored[3].

An investigation into aerobic biological wastewater treatment was conducted over the temperature range $25-75^{\circ} \mathrm{C}$ in a semi-batch bioreactor using waste metalworking fluids (MWFs) generated from Liverpool John Moores University's engineering workshop. The best treatment performance in terms of chemical oxygen demand (COD) removal occurred at $50^{\circ} \mathrm{C}(97.27 \%)$, with an operational time of $77.5 \mathrm{~h}$. Cell viability was observed throughout the operation and it was found that higher temperature did not directly correlate to low viability. Effluent turbidity reduced considerably from 35 to $50^{\circ} \mathrm{C}$ and increased thereafter. Even when the system encountered alkaline shock, the overall performance was not affected, thus indicating how stable the system was. The results of this study indicate that an existing industrial-activated sludge plant could be used to treat waste MWFs under thermophilic conditions. The COD reduction was significant but further investigation into biodegradation of recalcitrant compounds is needed to achieve optimum performance [4]. 


\section{Experimental Work}

To achieve the objective of this research, an experimental model system was planned and executed at al-Berka wastewater treatment plant and connected to one of tank of the plant ( in the primary treatment stage ) for supplying wastewater to the model.

The experimental model is operated as a continuous flow activated sludge with complete mix and constitutes a dual phase system wherein the heterotrophic bacteria are present in suspended form in the flowing wastewater and in attached form to the primary unit on the walls of the experimental model system.

\section{Description of the Experimental Model System}

The proposed research experimental setup consisted of a module plant for activated sludge aeration basin and an influent gas supply system, as demonstrated.

Figure (1) and Photo (1) illustrate scheduled and executed experimental model. The experimental model consists of two units, an aeration tank and a settling tank, or clarifier The aeration tank contains a "sludge" which is what could be best described as a "mixed microbial culture", containing mostly bacteria, as well as protozoa, fungi, algae, etc. This sludge is constantly mixed and aerated by compressed air bubblers located along the bottom. The aeration tank was constructed from Plexiglas and of dimensions $1.2 \times 1.2 \times 1.4 \mathrm{~m}$ having a working volume of $1.7 \mathrm{~m}^{3}$. The model contents are mixed using a variable speed mechanical stirrer. All the experiments except those designed to investigate the effect of mixing speed on sewage treatment are undertaken at a mixing speed of $100 \mathrm{rpm}$. A constant temperature is maintained by placing the tank in a controlled-temperature sewage model. Aerobic conditions are maintained in the model by intermittent supply of oxygen through four porous diffusers placed at the bottom of the aeration tank. The module plant consists of $0.25 \mathrm{~m}^{3}$ feeding cylindrical tank provided with a pump having max rate $50 \mathrm{~L} / \mathrm{min}$, and final tank cylindrical tank of $0.25 \mathrm{~m}^{3}$ volumes. In the aerobic tank the dissolved oxygen(DO) was maintained well above (2-4) $\mathrm{mg} / 1$ by intermittent injection of oxygen through a porous diffuser placed at the bottom of the aeration tank is mixed using and maintained at ambient temperature (average $25^{\circ} \mathrm{C}$ ), mixing is connected mechanically to pumps which feed the activated sludge reactors and air diffuser for the air pressure of 8 bar. The compressor supplies are at a rate air of 206 1/min.A flow system consist of a long rectangular tank, $1.2 \mathrm{~m}$ in depth, provided with aerators to supply oxygen for respiration, and to keep the activated sludge in suspension. The diffuser prevents the clogging of the aeration tank with activated sludge. It also serves the purpose of mixing contents and maintaining aerobic conditions in the aeration tank.

To achieve the research objectives, the current study is divided into two phases. The first phase was executed through the scheduled experimental program; while the second phase analysis of collected samples of AL-Berka treatment plant. A description of the experimental design, materials and experimental work used in both phases are given in the following sections.

The studied materials include sludge produced from the common wastewater treatment plant of AL-Berka for activated sludge used in the experimental model system. Sludge samples were collected from the eight scheduled runs. For each run of temperature $(10,15,20$, $25,30,35,40$ and $45^{\circ} \mathrm{C}$ ) respectively, four different samples were collected from experimental model. They were mixed thoroughly to produce a uniform composite sample and kept as one portion for the analysis of influent and effluent sewage properties ( $\mathrm{BOD}_{5}, \mathrm{COD}$, and S.S.). 


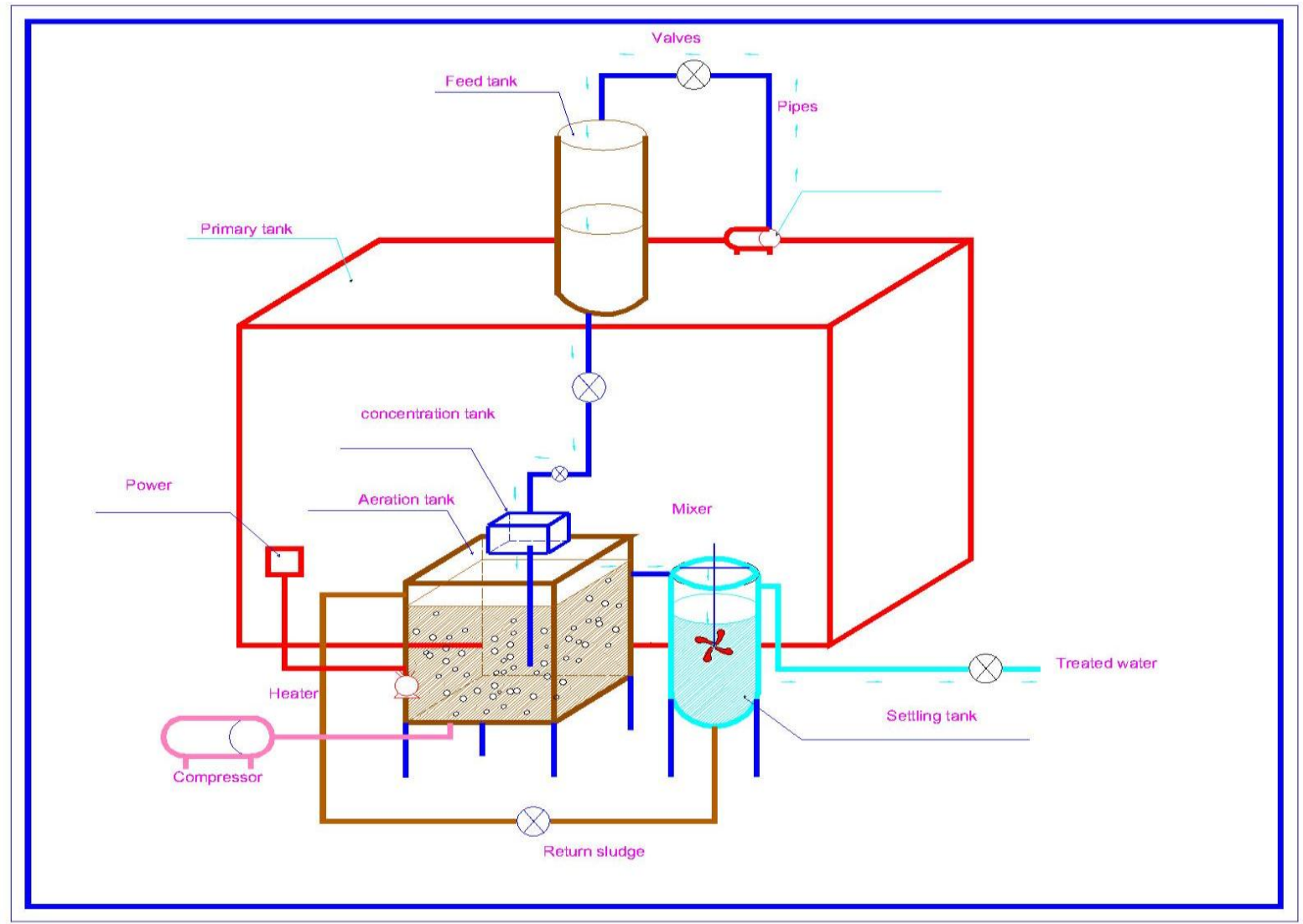

Figure (1) Diagrammatic sketch of the model system.

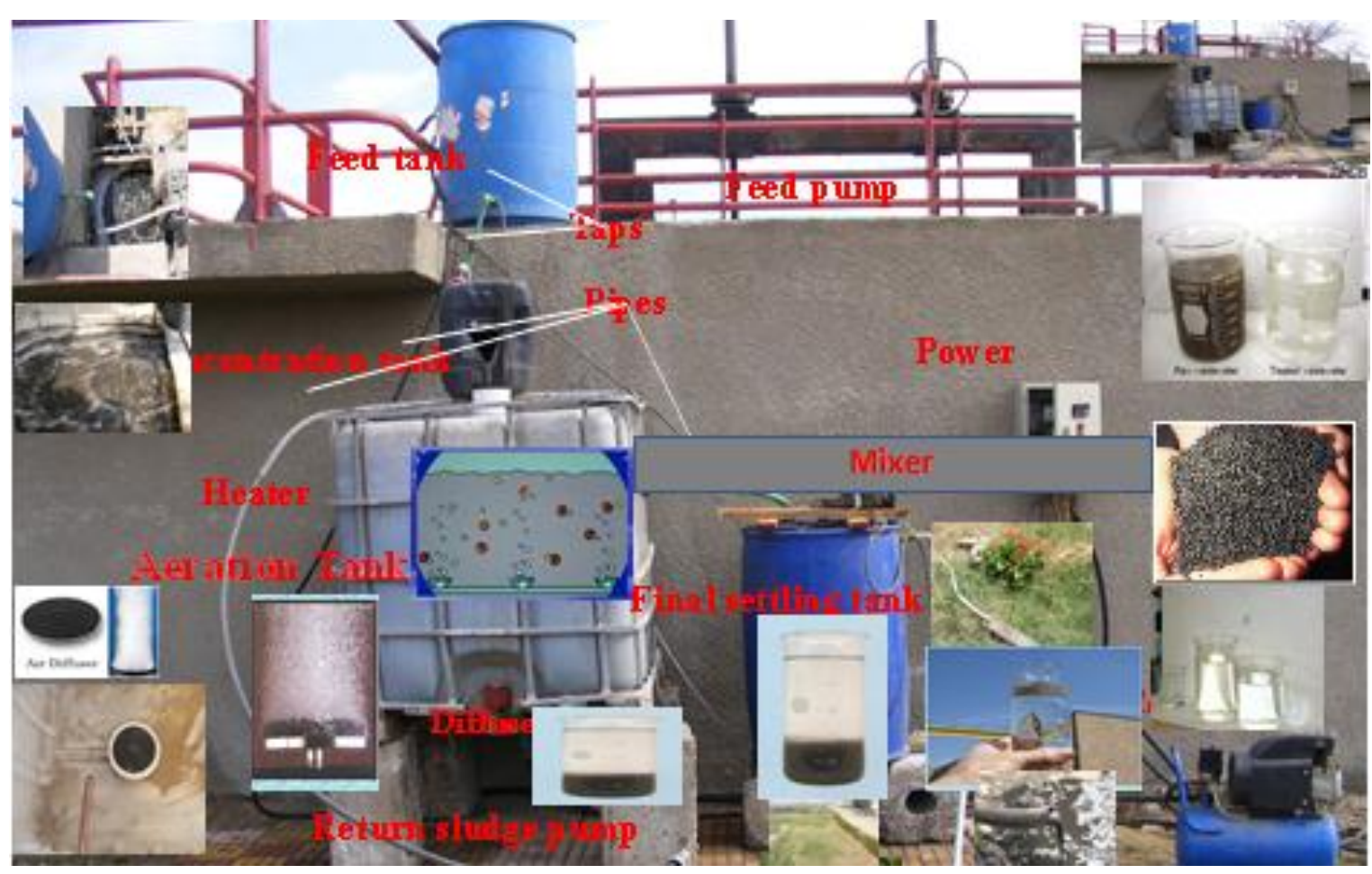

Photo (1) General view of the model system 


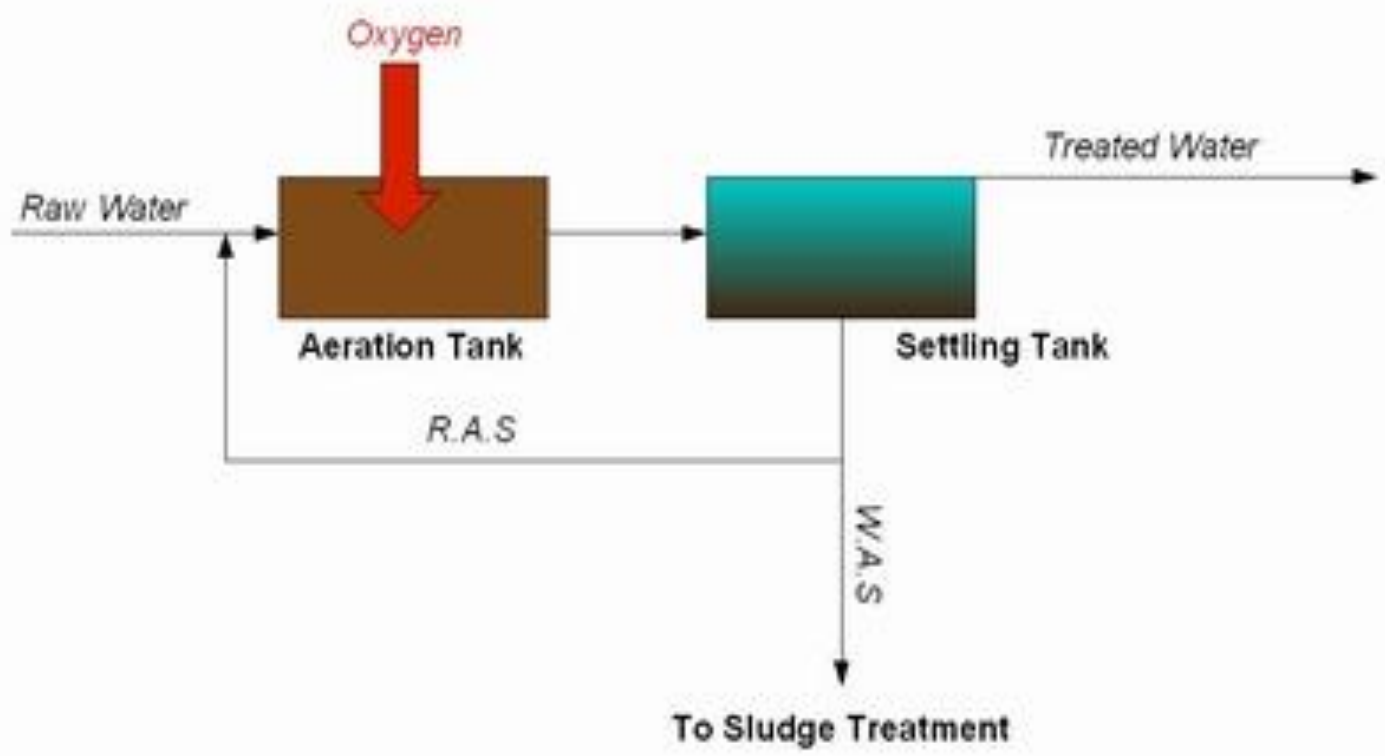

Figure (2) Aeration tank and settling tank plan

The relationships among temperature, dissolved oxygen required by diffuser aerators, and the efficiency of biological treatment process are achieved by measuring the reduction in $\left(\mathrm{BOD}_{5}\right.$, COD, and S.S). To achieve the previous objective, an experimental model is built and connected to one of the primary settling tank in Al-Berka Sewage Treatment Plant. The experimental model allows changing and stabilizing the ambient temperature of the model using heat control system. As previously mentioned, the scheduled temperature has been chosen to start at $10^{\circ} \mathrm{C}$ with intervals $5^{\circ} \mathrm{C}$ up to $45^{\circ} \mathrm{C}$. For each temperature, the dissolved oxygen ratio is changed till the highest efficiency by measuring ( $\mathrm{BOD}_{5}, \mathrm{COD}$, and S.S).

Finally the required dissolved oxygen for each temperature is stated in order to achieve the optimum efficiency. A record for instrument calibration each analysis day where applied, and be filed in an orderly manner so as to be readily available for inspection upon request. A calibration check standard is analyzed, the facility must document both the reading of the standard as well as the applicable acceptance range. Raw Sewage seems to be diluted to a reasonable extends but however the ratio of organic suspended solids to total organic is still in the range of complex wastewater category. After sufficient aeration time to reach the required level of treatment, the sludge is carried by the flow into the settling tank, or clarifier, producing a settling sludge and a reasonably clear upper or supernatant layer. If the sludge does not behave this way, a lot of solids will remain in the water leaving the clarifier, and the quality of the effluent wastewater will be poor. The sludge collected at the bottom of the clarifier is then recycled to the aeration tank to consume more organic material. The term "activated" sludge is used, because by the time the sludge is returned to the aeration tank, the microorganisms have been in an environment depleted of "food" for some time, and are in a "hungry", or activated condition, eager to get busy biodegrading some more wastes. Since the amount of microorganisms, or biomass, increases as a result of this process, some must be removed on a regular basis for further treatment and disposal. 


\section{Results and Discussion}

To achieve the research objectives, the current study was divided into two phases. The first phase was undertaken in the experimental model system; while the second phase was undertaken at the Central Laboratories for the sewage samples analysis.

\section{Calculation of Removal Efficiencies}

The soluble COD, S.S and $\mathrm{BOD}_{5}$ removal efficiencies for a given retention time were calculated on the basis of the soluble COD, S.S and $\mathrm{BOD}_{5}$ of the wastewater at the start of the experiment and after that retention time, without settling the effluent. The removal efficiency $\mathrm{R}$ is given by:

where:

$$
\mathrm{R} \%=100\left(\mathrm{~S}_{\mathrm{o}}-\mathrm{S}_{\mathrm{t}}\right) / \mathrm{S}_{\mathrm{o}}
$$

$\mathrm{R}=\mathrm{COD}$ or $\mathrm{BOD}_{5}$ removal efficiency $(\%)$ after $\mathrm{t}$ hours from the start of the experiment,

$\mathrm{S}_{\mathrm{o}}=\mathrm{COD}$ or $\mathrm{BOD}_{5}$ concentration $(\mathrm{mg} / 1)$ at the start of the experiment, and

$\mathrm{S}_{\mathrm{t}}=\mathrm{COD}$ or $\mathrm{BOD}_{5}$ concentration $(\mathrm{mg} / 1)$ after $\mathrm{t}$ hours from the start of the experiment.

The amount of soluble COD removal $(\mathrm{mg} / 1)$ over a given retention time ( $\mathrm{t}$ hours) was found as follows:

$$
\mathrm{R} \% \mathrm{SCOD}=\left(\mathrm{S}_{\mathrm{o}}-\mathrm{St}\right)
$$

where: $\mathrm{RSCOD}=$ soluble COD removal $(\mathrm{mg} / 1)$ after a given retention time $\mathrm{t}$ (hours). Sludge samples were collected from the eight scheduled runs $\left(10,15,20,25,30,35,40\right.$ and $\left.45^{\circ} \mathrm{C}\right)$ respectively. Four different samples were collected from experimental model and were mixed thoroughly to produce a uniform composite sample and kept as one portion for the analysis of influent and effluent sewage properties $\mathrm{BOD}_{5}, \mathrm{COD}$, and S.S effluent.

In this study it was found that the used technique achieved a removal ratio greater than $90 \%$ and the experimental model system and the total number of samples are summarized in Table (1).

Table (1) Total number of samples used in the experimental model for influent and effluent.

\begin{tabular}{c|c|c}
\hline \hline Parameters & Frequency & Total (10 Months study period) \\
\hline \hline S.S & $2 /$ week & 85 samples \\
\hline BOD $_{5}$ & $2 /$ week & 85 samples \\
\hline COD & 2/week & 85 samples \\
\hline \hline
\end{tabular}

\section{Operation Conditions of the Experimental Work}

During the eight runs, all operation conditions are maintained the same, except that the flow rates are changing, thus resulting in different hydraulic retention time in the aeration tank.

In the following sections the results of the eight different runs conducted are presented and discussed. Fittings of data of the above relations give the following 


\section{Run (1) at Temperature $\left(10^{\circ} \mathrm{C}\right)$}

The operation conditions of this run are as follows:

1. Influent flow rate $=1000$ lit/day,

2. Hydraulic retention time in aeration tank $=6$ hours.

3. The average influent (S.S, COD, BOD5, DO) to the aeration tank are $(273,668,347,4)$ $\mathrm{mg} / \mathrm{l}$ respectively.

4. The return sludge ratio $=20 \%$,

5. Dissolved oxygen in the aeration tank is maintained at $(4 \mathrm{mg} / \mathrm{l})$.

6. Food to microorganisms $(\mathrm{F} / \mathrm{M})$ ratio during 5 days period of the best operation ranges between 0,45 to 0,56 (mg COD/mg MLVSS),

7. $\mathrm{PH}$ value ranges between 6.5 to 6.7 ,

8. The mixed liquor suspended solids (MLSS) is $2700 \mathrm{mg} / \mathrm{L}$,

The average results obtained from the ten samples collected from the aeration tank of this run after analysis in laboratory are:

$\mathrm{S} . \mathrm{S}=100 \mathrm{mg} / \mathrm{l}, \mathrm{BOD}_{5}=100 \mathrm{mg} / \mathrm{l}, \mathrm{COD}=212 \mathrm{mg} / \mathrm{l}$,

Average removal efficiency: $\mathrm{S} . \mathrm{S}=63.4 \%, \mathrm{COD}=68.3 \%, \mathrm{BOD}_{5}=71.2 \%$.

The results of run (1) are concluded in Table (2) as well as the reference guidelines, and also illustrated in curves and bars shown in figures (3) to (5) respectively.

Table (2) Results of Run (1) for SS $\left(T=10^{\circ} \mathrm{C}, \mathrm{DO}=4 \mathrm{mg} / \mathrm{l}\right)$.

\begin{tabular}{l|c|c|c|c|c|c|c|c|c|c|c}
\hline \hline \multicolumn{1}{c|}{ Samples } & 1 & 2 & 3 & 4 & 5 & 6 & 7 & 8 & 9 & 10 & Average \\
\hline \hline Influent mg/l & 273 & 278 & 280 & 290 & 275 & 270 & 278 & 275 & 271 & 288 & 277.8 \\
\hline Effluent mg/l & 100 & 96 & 99 & 95 & 102 & 101 & 100 & 98 & 97 & 96 & 98.4 \\
\hline Removal \% & 63.4 & 65.5 & 64.6 & 67.2 & 63 & 61.5 & 64 & 64.4 & 64.2 & 66.6 & 64.44 \\
\hline Reference & 60 & 60 & 60 & 60 & 60 & 60 & 60 & 60 & 60 & 60 & 60 \\
\hline \hline
\end{tabular}

Inspecting the results obtained from run (1) considering average values, it is clear that:

(1)The influent S.S measured is $277.8 \mathrm{mg} / \mathrm{l}$, while it is $98.4 \mathrm{mg} / \mathrm{l}$ after applying the biological treatment which means a removal of $64.44 \%$ but still above the Egyptian standard value $(50 \mathrm{mg} / \mathrm{l})$.

(2)The influent $\mathrm{BOD}_{5}$ measured is $347 \mathrm{mg} / \mathrm{l}$, while it is $100 \mathrm{mg} / \mathrm{l}$ after applying the biological treatment which means a removal of $71.2 \%$ but still above the Egyptian standard value $(60 \mathrm{mg} / \mathrm{l})$.

(3)The influent CODS measured is $668 \mathrm{mg} / \mathrm{l}$, while it is $212 \mathrm{mg} / \mathrm{l}$ after applying the biological treatment which means a removal of $68.3 \%$ but still above the Egyptian standard value $(80 \mathrm{mg} / \mathrm{l})$. 


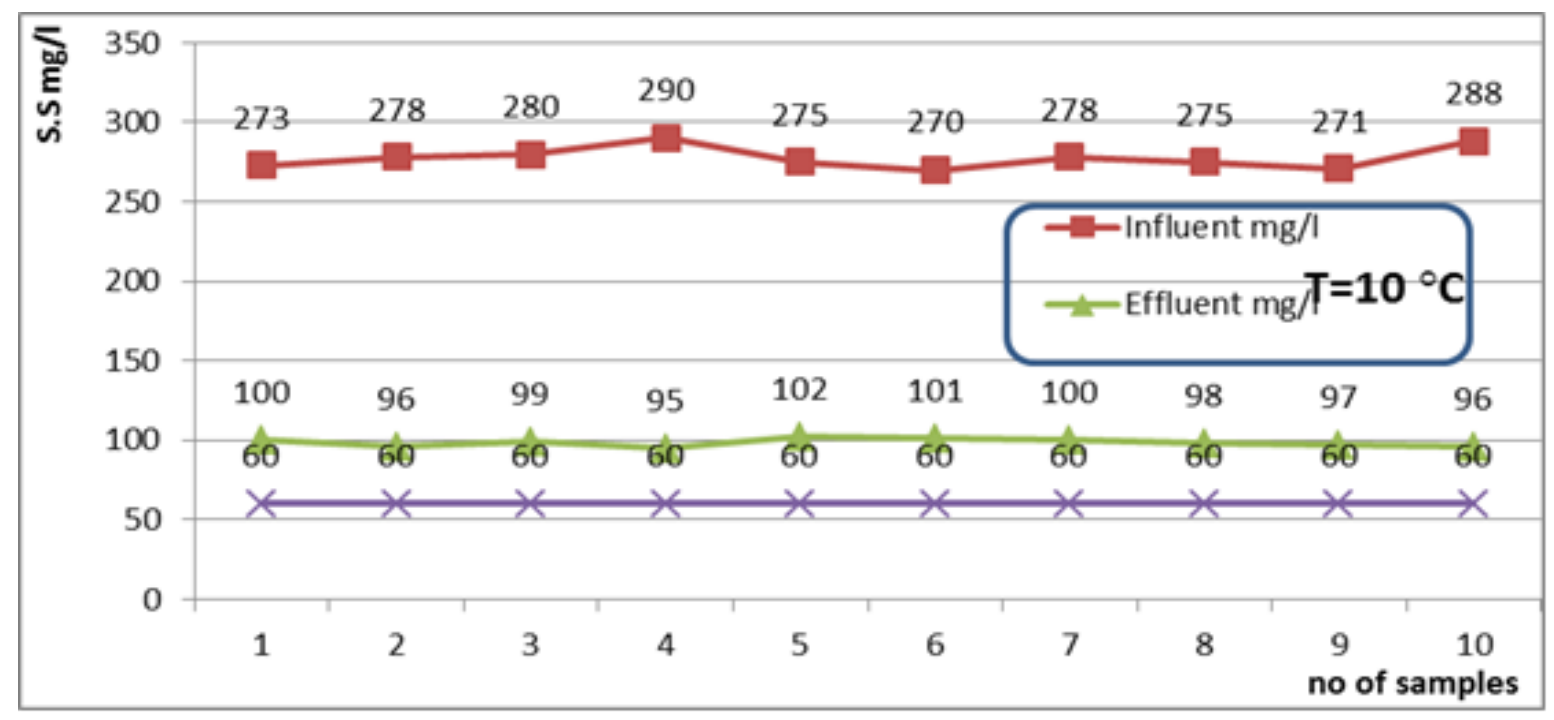

Figure (3) Results of Run (1) for SS $\left(\mathrm{T}=10^{\circ} \mathrm{C}, \mathrm{DO}=4 \mathrm{mg} / \mathrm{l}\right)$

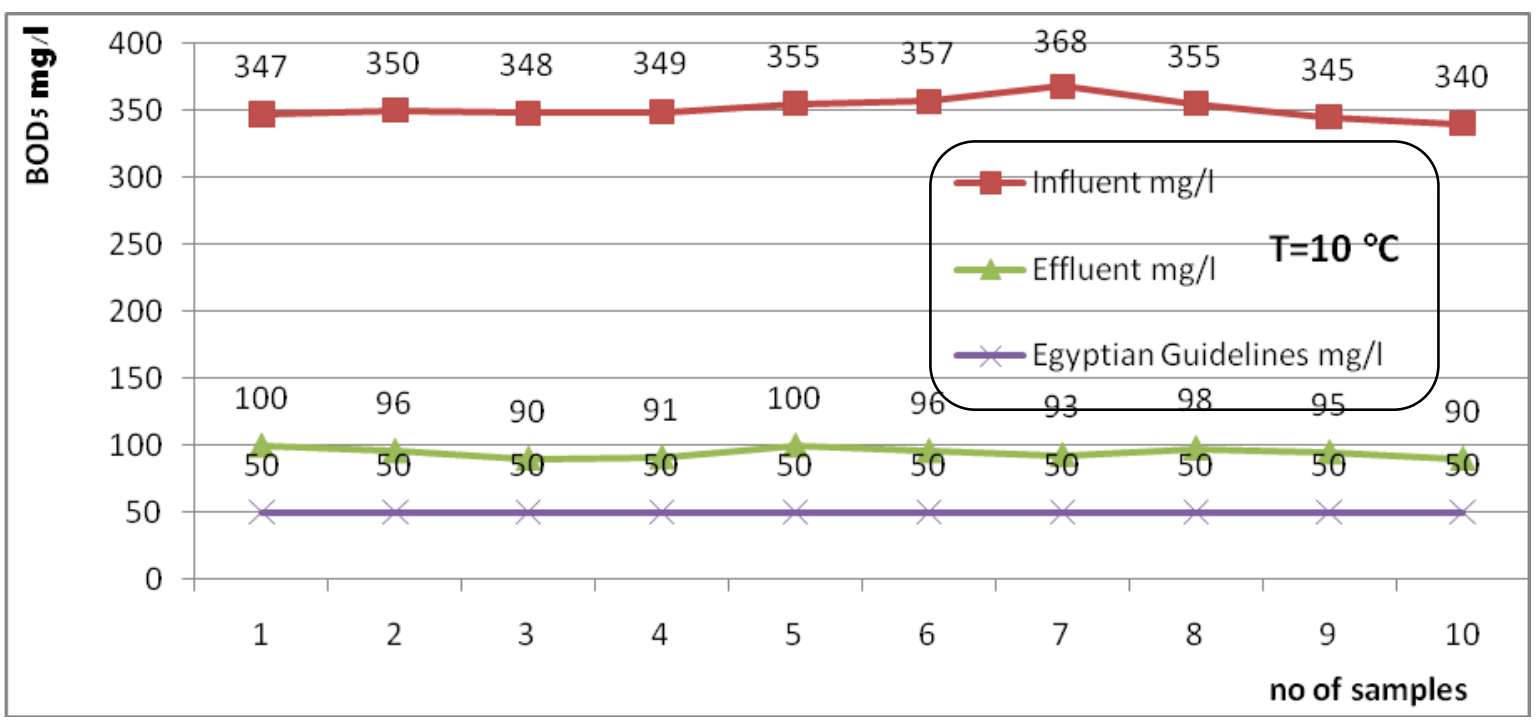

Figure (4) Results of Run (1) for BOD5 $\left(\mathrm{T}=10^{\circ} \mathrm{C}, \mathrm{DO}=4 \mathrm{mg} / \mathrm{l}\right)$

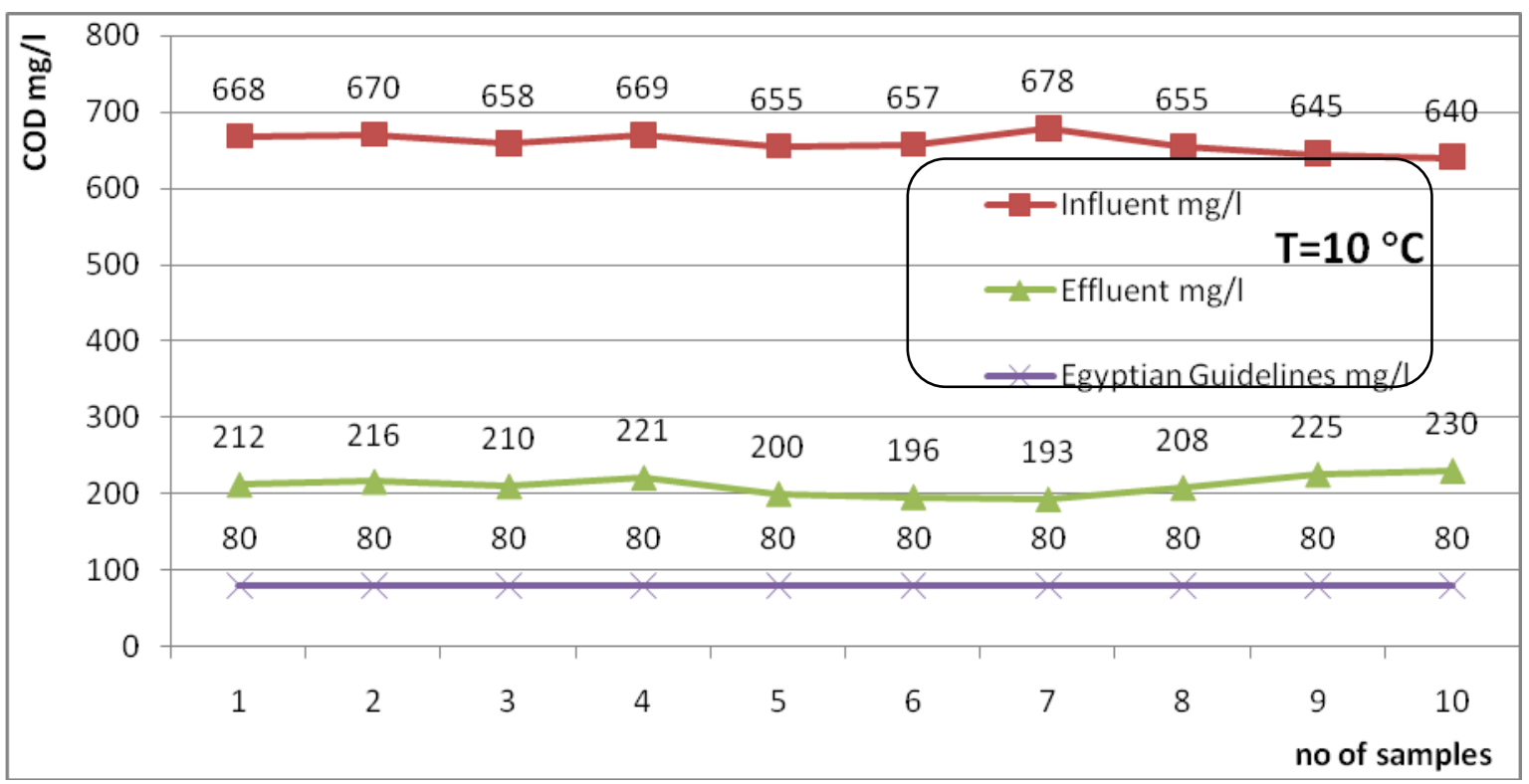

Figure (5) Results of Run (1) for COD (T=10 $\left.{ }^{\circ} \mathrm{C}, \mathrm{DO}=4 \mathrm{mg} / \mathrm{l}\right)$ 


\section{Run at Temperature $\left(25^{\circ} \mathrm{C}\right)$ :}

The operation conditions of the first are as follows:

1. Influent flow rate $=1000$ lit/day,

2. Hydraulic retention time in aeration tank $=6$ hours.

3. The influent $\left(\mathrm{S} . \mathrm{S}, \mathrm{COD}, \mathrm{BOD}_{5},\right)$ are $(237,680,340,2) \mathrm{mg} / \mathrm{l}$ to the aeration tank at temperature $\left(25^{\circ} \mathrm{C}\right)$,

4. The return sludge ratio $=20 \%$,

5. The dissolved oxygen in the aeration tank was maintained within the desired range ( 2 to 4 $\mathrm{mg} / \mathrm{l})$.

6. The food to microorganisms $(\mathrm{F} / \mathrm{M})$ ratio during 5 days period of the best operation ranged between 0,45 to 0,56 (mg COD/mg MLVSS),

7. The $\mathrm{pH}$ value ranged between 6.5 to 6.7 ,

8. The mixed liquor suspended solids ranged between (MLSS) is $2700 \mathrm{mg} / \mathrm{L}$,

9. The results obtained for this run after the analysis of the collected samples are:

$\mathrm{S} . \mathrm{S}=18 \mathrm{mg} / \mathrm{l}, \mathrm{COD}=36 \mathrm{mg} / \mathrm{l}, \quad \mathrm{BOD}_{5}=16 \mathrm{mg} / \mathrm{l}$, Removal efficiency: $\mathrm{S} . \mathrm{S}=93 \%$, $\mathrm{COD}=95 \%, \mathrm{BOD}_{5}=96 \%$,

The results of run(4) are concluded with the reference guidelines, which its illustrated in curves and bars as shown in figures (6) to (8) respectively .

Inspecting the results obtained from run (4) considering average values, it is clear that:

(1)The influent S.S measured is $237 \mathrm{mg} / \mathrm{l}$, while it is $18 \mathrm{mg} / \mathrm{l}$ after applying the biological treatment which means a removal of $93 \%$ but still above the Egyptian standard value $(60 \mathrm{mg} / \mathrm{l})$.

(2)The influent $\mathrm{BOD}_{5}$ measured is $340 \mathrm{mg} / \mathrm{l}$, while it is $16 \mathrm{mg} / \mathrm{l}$ after applying the biological treatment which means a removal of $97 \%$ but still above the Egyptian standard value $(50 \mathrm{mg} / \mathrm{l})$.

(3)The influent COD measured is $650 \mathrm{mg} / \mathrm{l}$, while it is $36 \mathrm{mg} / \mathrm{l}$ after applying the biological treatment which means a removal of $95 \%$ but still above the Egyptian standard value $(80 \mathrm{mg} / \mathrm{l})$.

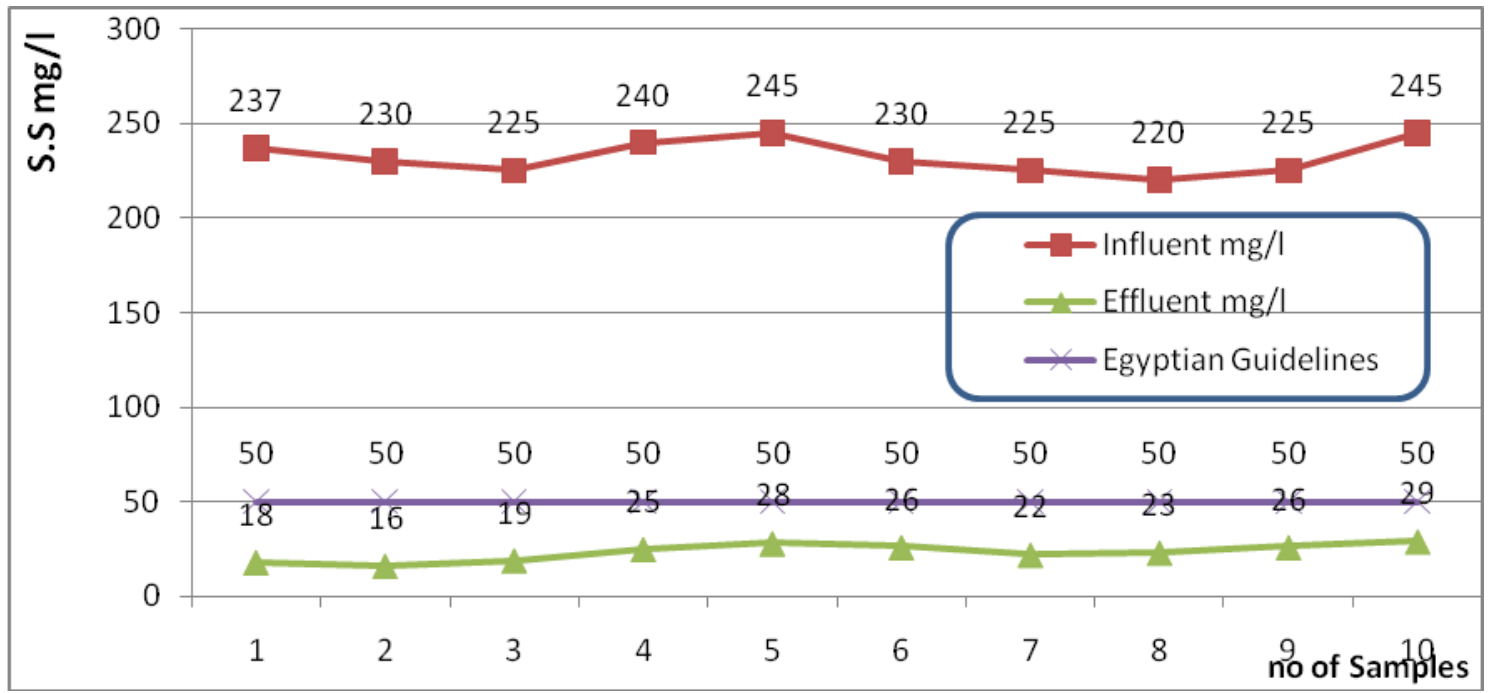

Figure (6) Results of Run for parameter S.S. $\left(\mathrm{Temp}=25^{\circ} \mathrm{C}, \mathrm{DO}=2 \mathrm{mg} / \mathrm{l}\right)$ 


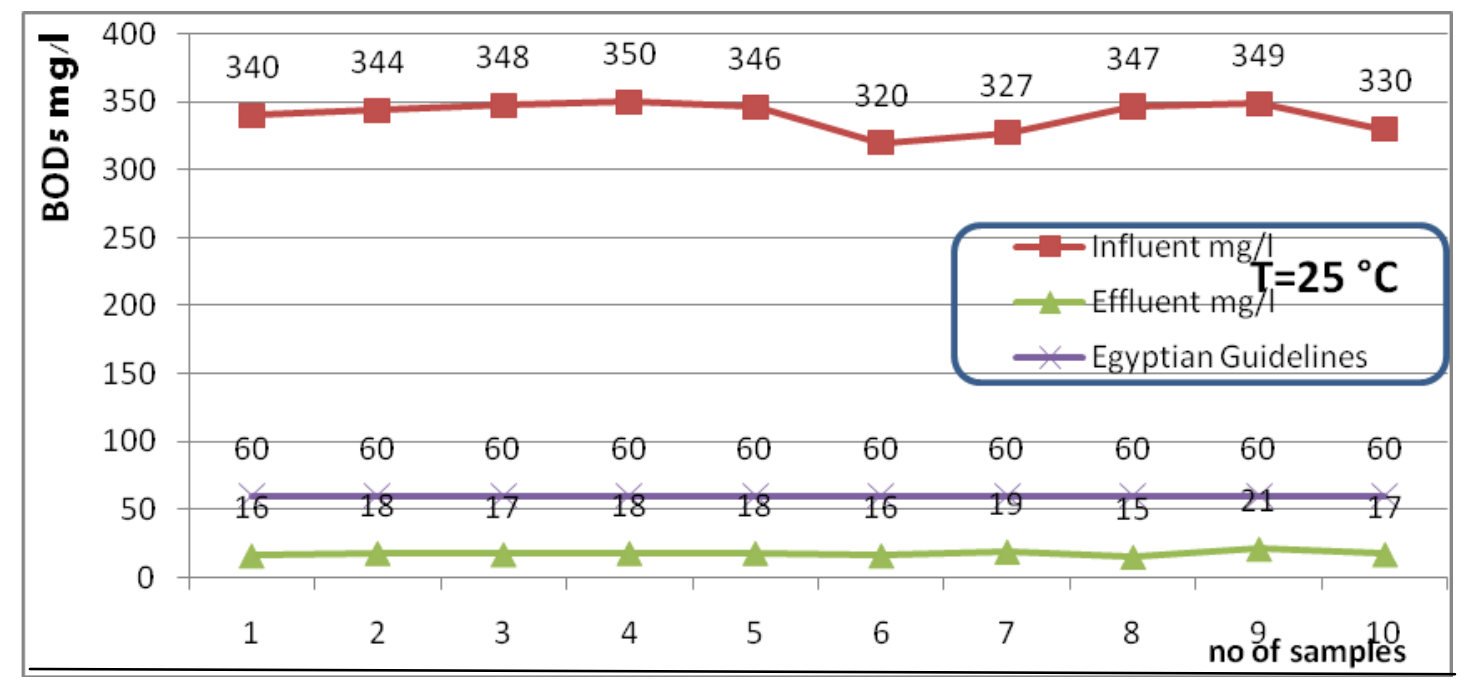

Figure (7) Results of Run for parameter $\mathrm{BOD}_{5}(\mathrm{DO}=\mathbf{2 m g} / \mathrm{l})$

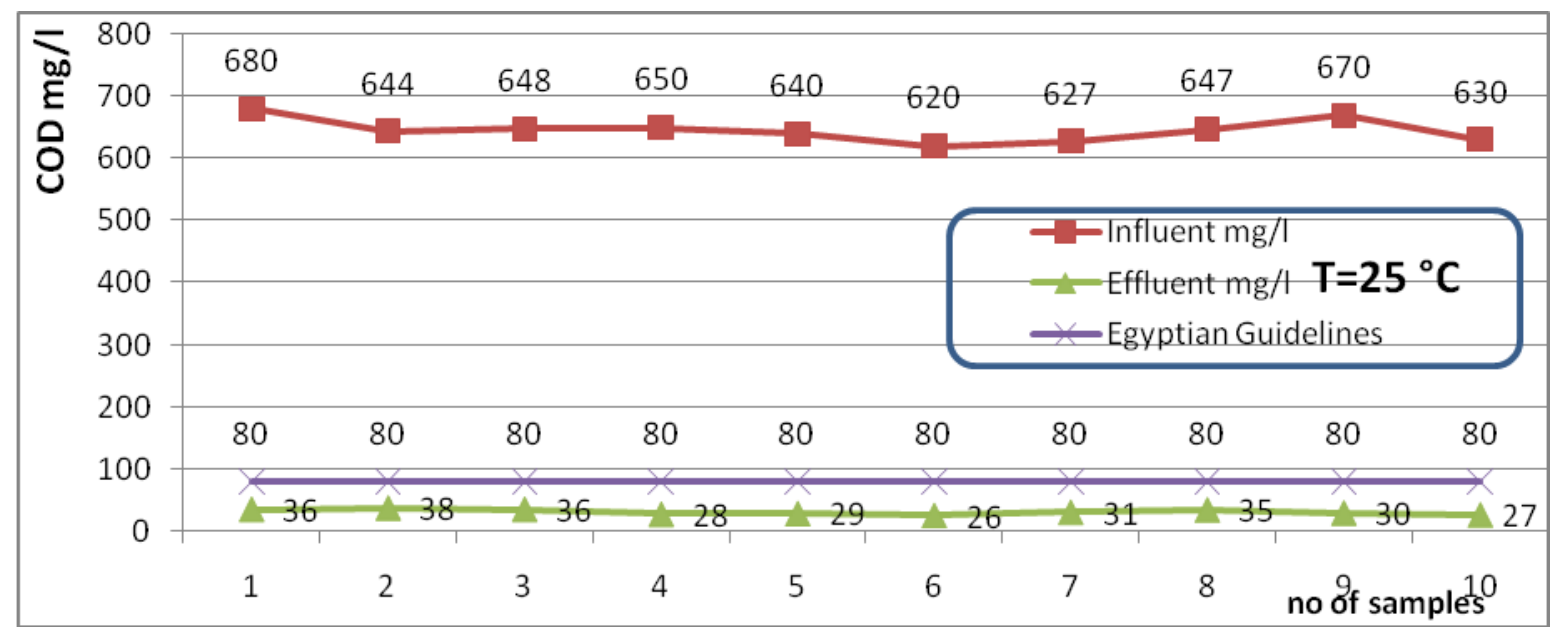

Figure (8) Results of Run for parameter COD $(\mathrm{DO}=\mathbf{2 m g} / \mathrm{l})$.

\section{Run (1-8) at Temperature $\left(10-45^{\circ} \mathrm{C}\right)$ :}

It was noticed that the effluent concentration were not reduced to values compatible with the limits stated. Data summarizing the average (S.S, BOD $5, C O D$ ) removal efficiencies for different wastewaters are shown In figures (9) and (10) while the corresponding influent indicates that, when compared with the Egyptian standards Guidelines ,

The diagrams can be used to design secondary clarifiers and to evaluate operational control options whenever there are changes in clarifier $\left(\mathrm{S} . \mathrm{S}, \mathrm{BOD}_{5}, \mathrm{COD}\right)(\mathrm{mg} / \mathrm{l})$ settling characteristics.

The following elements might be taken into account when considering the optimum removal. This gives an indication that optimum DO concentration regarding minimum cost at $\left(25^{\circ} \mathrm{C}\right)$ and more $95 \%$ without nitrification and phosphorus. Generally the bacterial reaction rate approximately doubles for each $25^{\circ} \mathrm{C}$ rise in temperature estimate the temperature sensitivity of the $\left(\mathrm{S} . \mathrm{S}, \mathrm{BOD}_{5}, \mathrm{COD}\right)$ removal rates in the wastewater, 


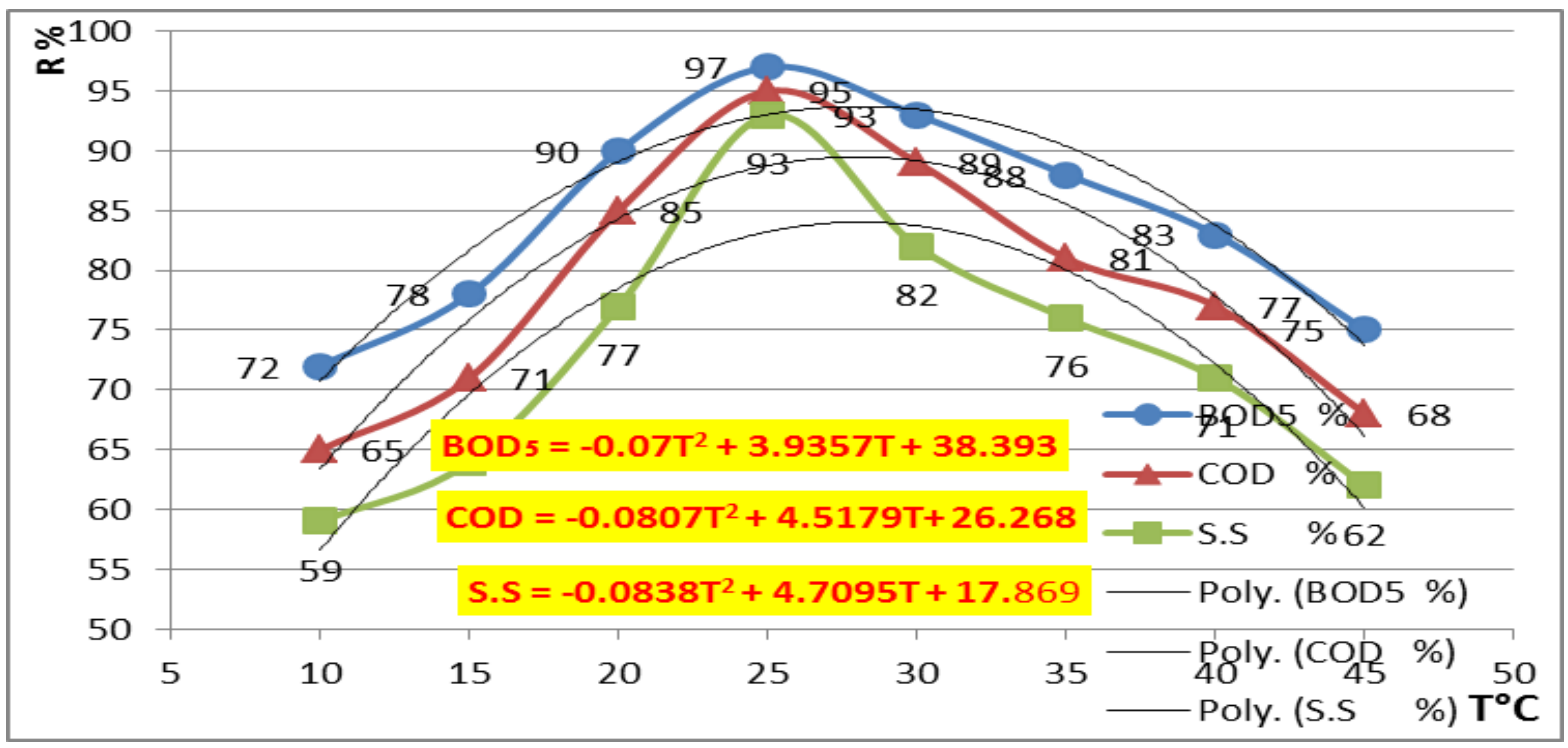

Figure (9) Relation results (curves) at $\mathrm{Temp}\left(10-45^{\circ} \mathrm{C}\right)$ and removal of BOD5, COD, and S.S.

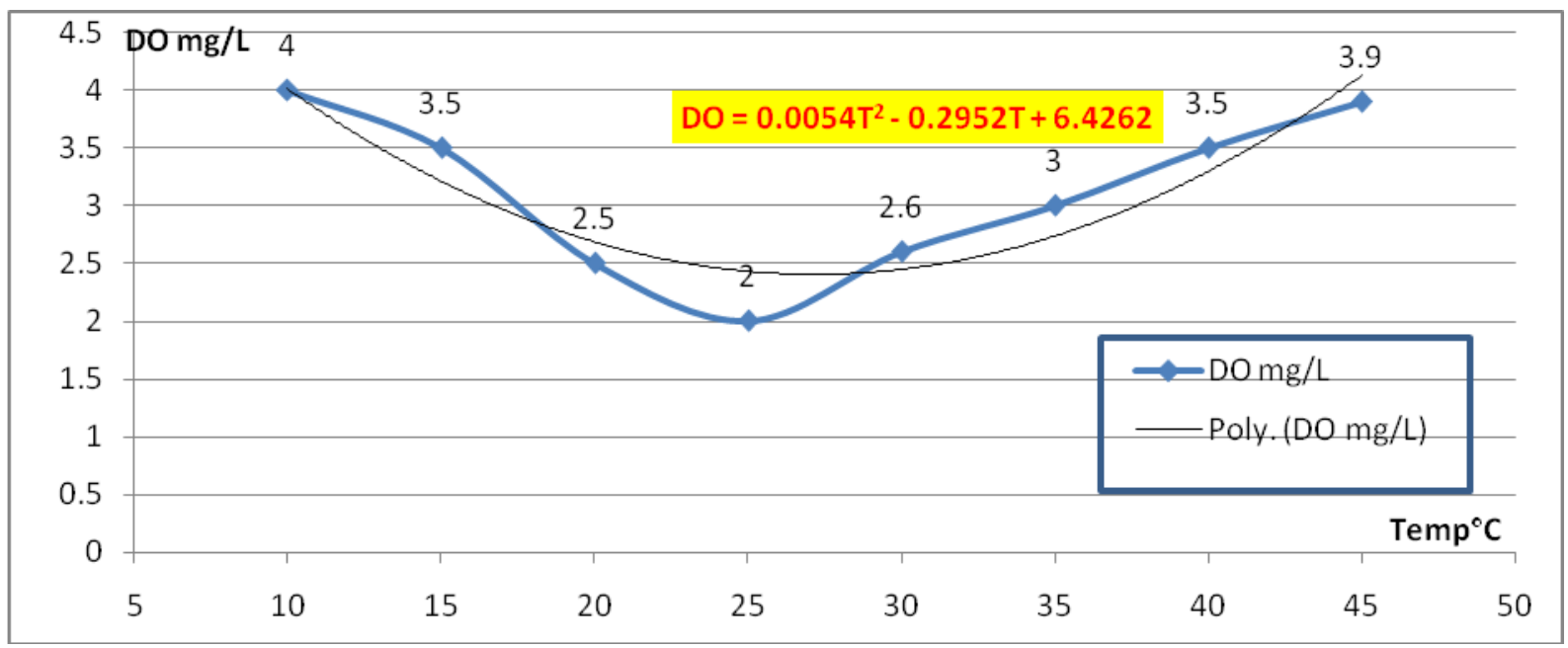

Figure (10) Relation results of dissolved oxygen (DO) and temperature (10-45 $\left.{ }^{\circ} \mathrm{C}\right)$

\section{Conclusions}

Under specific condition that been discussed before the following conclusions are drawn from this research:

1. Ambient temperature has a significant effect on biological treatment for nearly same dissolved oxygen.

2. At temperature $\left(25^{\circ} \mathrm{C}\right)$, the removal efficiencies of the parameters: suspended solids (S.S), chemical oxygen demand (COD) and biological oxygen demand $\left(\mathrm{BOD}_{5}\right)$ removal are the best. The relation between the temperature $\left(\mathrm{T}^{\circ} \mathrm{C}\right)$ and these parameters can be expressed by the equations:

S.S R \% $=-0.0881 \mathrm{~T}^{2}+5.2167 \mathrm{~T}+9.2262$

COD R \% $=-0.1 \mathrm{~T}^{2}+5.5714 \mathrm{~T}+13.036$

BOD5 R \% $=-0.0948 \mathrm{~T}^{2}+5.2738 \mathrm{~T}+19.071$ 
3. The relation between the temperature $\left(\mathrm{T}^{\circ} \mathrm{C}\right)$ and the required dissolved oxygen (DO) can be expressed by the equation:

$$
\text { DO mg/l }=0.0054 \mathrm{~T}^{2}-02952 \mathrm{~T}+6.4262
$$

The minimum DO required for minimum cost biological treatment is found at temperature $25^{\circ} \mathrm{C}$.

4. In the highest temperature in aeration tank $(40-45)^{\circ} \mathrm{C}$ removal efficiency decreased regardless of DO \% due to the existence of Filamentous sludge bulking that cause floating on the sewage.

\section{References}

[1] Gh Ghanizadeh1at all..,The Effects of Temperature and PH on Satiability of Activated Sludge Flocs of Environmental Health Engineering, Faculty, Tehran, Iran.

[2] R.O. Mines Jr.: Biomedical/Environmental Engg. Dept., Mercer University, 1400 Coleman Avenue, Macon, GA 31207, US Journal of Environmental Science and Health

[3] Harbin Gongye Daxue Xuebao/Journal of Harbin Institute of Technology, August 2007 B.-L. Zhang: Daqing Oilfield Engineering Ltd., , China,

[4] UK.Christina Cheng, Water and Environment Journal, December 2006C., Liverpool John Moores University, Byrom Street, Liverpool L3 3AF, 2005. 